\title{
Article \\ Effects of Crop-Hedgerow Intercropping on the Soil Physicochemical Properties and Crop Yield on Sloping Cultivated Lands in a Purple Soil of Southwestern China
}

\author{
Ping Lei ${ }^{1,2} \oplus$, Chengsheng Ni ${ }^{1}\left(\mathbb{D}\right.$, Fangxin Chen ${ }^{1}$, Sheng Wang ${ }^{1}$, Shouqin Zhong ${ }^{1}$, Shaojun Tan ${ }^{1}$, Jiupai Ni ${ }^{1}$ \\ and Deti Xie ${ }^{1, *}$ \\ 1 College of Resources and Environment, Southwest University, Chongqing 400715, China; \\ tracy7909@163.com (P.L.); nichengsheg@163.com (C.N.); fangxinchen@swu.edu.cn (F.C.); \\ shengwang@swu.edu.cn (S.W.); zhong.qing.1988@163.com (S.Z.); tsj2015@126.com (S.T.); \\ nijiupai@163.com (J.N.) \\ 2 School of Urban and Rural Planing and Constrution, Mianyang Teachers' College, Mianyang 621000, China \\ * Correspondence: xdt@swu.edu.cn
}

check for

updates

Citation: Lei, P.; Ni, C.; Chen, F.; Wang, S.; Zhong, S.; Tan, S.; Ni, J.; Xie, D. Effects of Crop-Hedgerow Intercropping on the Soil

Physicochemical Properties and Crop Yield on Sloping Cultivated Lands in a Purple Soil of Southwestern China. Forests 2021, 12, 962. https:// doi.org/10.3390/f12080962

Academic Editor: Douglas Godbold

Received: 5 June 2021

Accepted: 14 July 2021

Published: 21 July 2021

Publisher's Note: MDPI stays neutral with regard to jurisdictional claims in published maps and institutional affiliations.

Copyright: (c) 2021 by the authors. Licensee MDPI, Basel, Switzerland. This article is an open access article distributed under the terms and conditions of the Creative Commons Attribution (CC BY) license (https:/ / creativecommons.org/licenses/by/ $4.0 /)$.

\begin{abstract}
Crop-hedgerow intercropping systems are important agroforestry systems for preventing soil degradation and soil nutrient losses on sloping cultivated land in the Three Gorges Reservoir (TGR) area of China. However, the mechanism by which hedgerow spatial layouts and the planting patterns affect soil nutrients and crop yields is still uncertain. A two-year field experiment was performed on a $10^{\circ}$ slope to investigate the effects of slope position and different crop-hedgerow intercropping systems on soil physicochemical properties and crop yields. The treatments were a two-belt mulberry contour hedgerow (TM), a two-belt compound mulberry-vetiver hedgerow (TCMV), a two-belt compound mulberry-alfalfa hedgerow (TCMA), a seven-year-old two-belt mulberry contour hedgerow (7YTM), a seven-year-old mulberry border hedgerow (7YBM), a seven-yearold pure mulberry (7YPM), and a control treatment (CT, no hedgerows). In all treatments, except 7YPM, there was a significant $(p<0.05)$ increase in crop yield, clay content, soil total nitrogen (STN), acid-hydrolyzable nitrogen (AHN), and soil organic carbon (SOC) with declining slope position, whereas soil bulk density (BD), sand content, and soil pH showed the opposite trend. In TM, TCMV, TCMA, and 7YTM, the mustard yields and soil properties were better than those in CT, and there was no significant $(p>0.05)$ difference in mustard yield or soil properties between the upper-middle and lower-middle slope positions. Compared with CT, TCMV, and TCMA increased mustard yields by $8.28 \%$ and $9.86 \%$, respectively, while 7YTM, 7YBM, and 7YPM reduced mustard yields by $7.69 \%$, $17.69 \%$, and $29.73 \%$, respectively. TCMV and TCMA were confirmed to be viable intercropping systems for significantly reducing nutrient losses, improving soil quality, and changing soil nutrient distributions to maintain optimum crop yields on sloping lands.
\end{abstract}

Keywords: agroforestry; crop-hedgerow intercropping system; soil physicochemical properties; crop yield; spatial variability; purple soil

\section{Introduction}

The degradation of sloping agricultural lands and nutrient losses arising from soil erosion, excessive fertilizer use, environmental pollution, and unreasonable farming systems are two of the most severe environmental issues currently being confronted in numerous countries worldwide [1-4]. The soil erosion by water has been recognized as the main form of soil degradation in sloping agricultural lands and has a series of adverse effects, such as soil fertility reduction, soil organic matter loss, land productivity reduction, and water body pollution [5-8]. Soil degradation caused by soil erosion is inevitable, especially in the sloping farmlands of southwestern China, where high-energy rainstorms frequently occur [9-11]. Essential plant nutrients, soil organic matter, and fine clay particles are lost through soil erosion, which consequently reduces land productivity [12]. 
The heterogeneity of soil physicochemical properties (including bulk density (BD), soil texture, chemical composition, and organic matter content) within sloping farmland is primarily caused by the heterogeneity of intrinsic and extrinsic soil factors, such as discrepancies in the transport and deposition of eroded materials and soil management practices $[13,14]$. The heterogeneity of soil physicochemical properties and declining soil fertility are pervasive and, in turn, affect the growth and productivity of crops. Therefore, understanding the spatial heterogeneity of soil physicochemical properties is essential for determining best practices for soil management, especially in the hilly areas of southwestern China that have a high population density and serious soil erosion.

The Three Gorges Reservoir area, an ecologically fragile area of southwest China that experiences serious soil erosion, is hilly and has low forest coverage; more than $70 \%$ of the land surface in this area is vulnerable to soil erosion [15]. Sloping farmland accounts for $42 \%$ of the total cultivated land, and $64 \%$ of the sloping farmland has a slope steeper than $15^{\circ}$ [16]. The unreasonable culturing caused by insufficient arable land, low soil cover, and low organic carbon inputs have led to serious soil erosion conditions and related nutrient losses $[16,17]$. Therefore, it is crucial to select and adopt appropriate protective measures to minimize soil erosion in the region to maintain food productivity and environmental security.

Increasing nutrient inputs and decreasing nutrient losses are two common ways to restore depleted soil nutrients. Generally, chemical and organic fertilizers are used to compensate for the loss of soil nutrients caused by soil erosion, but the excessive use of chemical fertilizers inevitably brings about the risk of environmental pollution [10,18].

Agroforestry systems are important, affecting 1.2 billion people globally and covering 600 million hectares of land [19]. Contour hedgerow systems, as a kind of agroforestry system, are widely considered to be simple, low-cost, and effective systems for controlling soil erosion and nutrient loss on sloping farmlands [15,20,21]. In recent years, contour hedgerows have become the main approach for soil and water conservation in sloping farmlands in southern China [22,23].

Contour hedgerows can reduce runoff, soil erosion [24,25], and nonpoint source pollution by reducing soil nutrient loss [21], thus restoring fertility and maintaining optimum crop yields [20]. Oshunsanya et al. [26] reported that vetiver grass hedgerows could increase maize yields and reduce runoff and sediment nutrient pollutant discharged from sloping land when compared to plots with the sole organic or inorganic fertilizer. Lenka et al. [7] reported that Gliricidia sepium with grass filter strips reduced runoff by $33 \%$, soil loss by $35 \%$, and soil organic carbon (SOC) loss in runoff by $50 \mathrm{~kg} \mathrm{ha}^{-1} \mathrm{yr}^{-1}$.

Crop-hedgerow intercropping, a typical agroforestry technique, is a sustainable agricultural system that involves the intentional combination of tree, shrub, and herb growth with crop cultivation and livestock production. Selecting appropriate hedgerow species and filtration belt arrangements can result in runoff dispersal and retention, sediment transport and nutrient loss prevention on slopes, and soil organic matter accumulation. Mulberry, a deciduous shrub, has been identified as one of the best choices for ecological restoration and environmental protection because of its well-developed root system, ease of cultivation, and strong ecological adaptability and resilience [11,15]. According to the research of Chen et al. [27], mulberry is a particularly important economic crop in the TGR area, and the output value of mulberry accounts for approximately $30 \%$ of the total agricultural output value from the area. Therefore, using mulberry, a traditional value-added crop in the TGR region, as a hedgerow species could also address the economic interests of local farmers.

At present, crop-hedgerow intercropping has become one of the most common farming modes in the TGR region; it can effectively control soil erosion, prevent land degradation, and protect biodiversity. Although mulberry has a dense canopy covering the soil, there are gaps between its lowest branches and the ground, it is bound to cause runoff to pass through these gaps, resulting in the loss of soil and nutrients. However, herbaceous plants exhibit dense growth habits and high plant density, and have the characteristics 
of well-developed root systems, more abundant fibrous roots, and strong tiller; for these reasons, they can effectively prevent the loss of fertile surface soils and rill erosion [28]. By using the characteristics of the spatial distribution of shrubs and herbaceous plants in different levels, they can intercept, buffer, and drain the rainwater, reduce the erosion of rainwater on the slope soil, and effectively control the phenomenon of soil erosion.

The interception of soil erosion by hedgerows inevitably results in the soil nutrient exhibiting spatial heterogeneity. Most studies on the spatial heterogeneity of nutrients have generally focused on the variation in soil physicochemical properties on different slopes within large-scale landscapes, while studies at different runoff scales have focused only on the impact of slope length on runoff and sediment loss [29-31]. However, the spatial variability in the soil properties of sloping farmland at smaller scales is not yet fully understood. At the runoff plot scale, many scholars have investigated the water and soil conservation effects of crop-hedgerow intercropping systems, but the influence of slope position on soil physicochemical properties has not received enough attention $[7,21,32]$. Understanding the spatial heterogeneity of soil physicochemical properties is vital for determining best practices that can simultaneously control soil erosion and improve intercropping system productivity. Therefore, this study took crop-hedgerow intercropping systems in runoff plots in the Wangjiagou watershed in the TGR region as its research object, discussed the effect of different hedgerow arrangements and slope positions on crop yield and soil properties, and described the relationships between changing soil environmental conditions and crop yields. The goal of this study was to provide overarching insights for use in the formulation of soil and water conservation measures in a hilly, purple-soil area of China.

\section{Materials and Methods}

\subsection{Site Description}

This study was carried out over four consecutive growing seasons from 2017 to 2019 in the Wangjiagou catchment $\left(107^{\circ} 30^{\prime} \mathrm{E}\right.$ and $\left.29^{\circ} 54^{\prime} \mathrm{N}\right)$, which is located in the town of Zhenxi, Fuling District, in the hinterland of the Three Gorges region of China. This region experiences a tropical/mid-subtropical humid monsoon climate. The mean daily annual temperature is $22.10^{\circ} \mathrm{C}$, the average annual precipitation is $1011 \mathrm{~mm}$, the frost-free period is approximately 317 days per year, and the annual sunshine duration is $1248 \mathrm{~h}$. Sixty-six percent of the annual total precipitation occurs in summer and autumn in the form of high-intensity rainstorms. According to the Bureau of Geology and Mineral Resources of Sichuan Province and field research, in this area, the soils are developed from the purple rock strata of the Jurassic system [27]. The purple parent rock is loose and easily physically decomposed, making it susceptible to erosion by rainfall and scouring. The purple soil in this region usually occupies a shallow soil layer of less than $50 \mathrm{~cm}$ in depth, though it will very rarely reach more than $1 \mathrm{~m}$ in depth. Mulberry and mustard are important economic crops in this region. The most common crop rotations are mustard-rice in paddy fields and mustard-corn in dry lands.

\subsection{Experimental Design}

A total of 21 experimental plots $5 \mathrm{~m}$ wide and $10 \mathrm{~m}$ long were constructed on dry sloped land with a slope of $10 \%$. The plots had good interception drainage and embankments on the upper and lower sides. All experimental plots were enclosed by brick-concrete partition walls that reached approximately $20 \mathrm{~cm}$ above the soil surface and at least $30 \mathrm{~cm}$ below the soil surface to prevent lateral water movement. In addition, a catch pond $(2 \mathrm{~m} \times 1 \mathrm{~m})$ was constructed at the toe of each plot, and a cutoff drain was constructed on the upper side. The experiment comprised seven treatments arranged in a randomized complete block design with three replications, including control (CT; no hedgerows), a two-belt contour mulberry (Morus alba L.) hedgerow (TM), a two-belt compound mulberryvetiver (Vetiveria zizanioides L.) hedgerow (TCMV), a two-belt compound mulberry-alfalfa (Medicago sativa L.) hedgerow (TCMA), a 7-year-old two-belt contour mulberry hedgerow 
(7YTM), a 7-year-old border mulberry hedgerow (7YBM), and a 7-year-old pure mulberry (7YPM) treatment. The hedgerows were planted in the field according to the schematic diagram in Figure 1. For the TM, TCMV, TCMA, and 7YTM treatments, each belt of a mulberry hedge was composed of two rows of mulberry trees with a row spacing of $80 \mathrm{~cm}$ and a plant spacing of $30 \mathrm{~cm}$. In the TCMV and TCMA treatments, the corresponding herbaceous filter was planted between the two rows of mulberry trees by digging holes with a vegetable shovel. The distance between the holes was $10 \mathrm{~cm}$, and five to six seeds were sown in each hole. The seeds were covered with fine soil and stepped on to compress the soil. When the seeds sprouted, 1 to 2 healthy sprouts were retained, and the rest were removed or transplanted. Moreover, since we were interested in investigating the variation in physicochemical properties along the slope, the plots were further subdivided into four slope positions: the upper ( $1.2 \mathrm{~m}$ from the uppermost part of the plot), upper-middle ( $3.2 \mathrm{~m}$ from the uppermost part of the plot), lower-middle ( $6 \mathrm{~m}$ from the uppermost part of the plot) and lower (8 $\mathrm{m}$ from the uppermost part of the plot) slope positions (Figure 1).
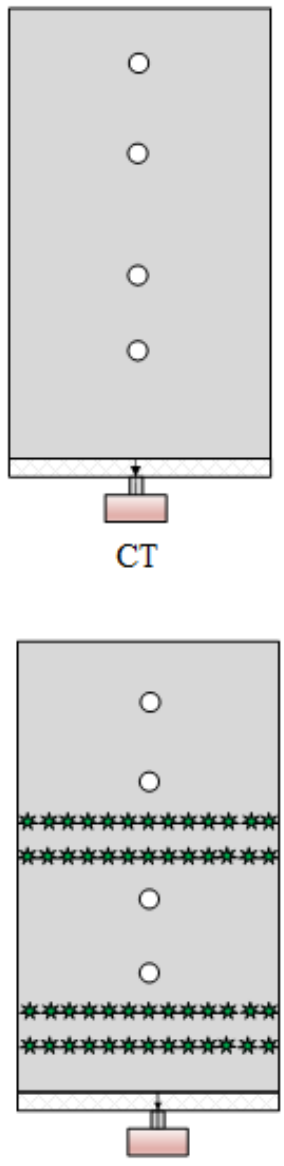

Y7TM

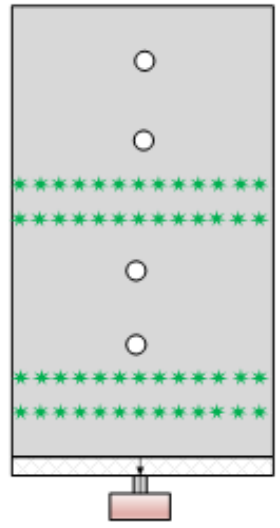

TM

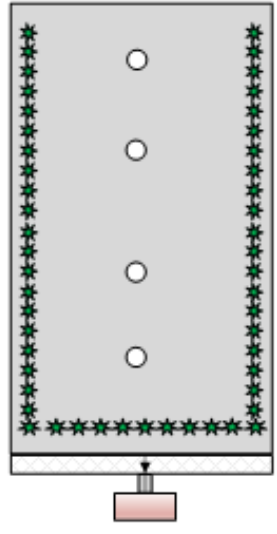

$7 \mathrm{YBM}$

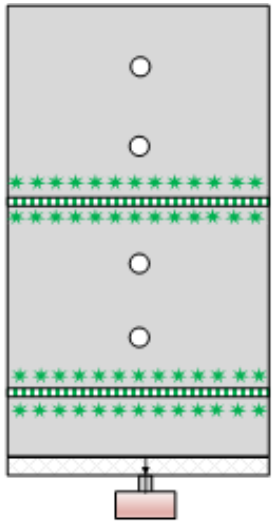

TCMV

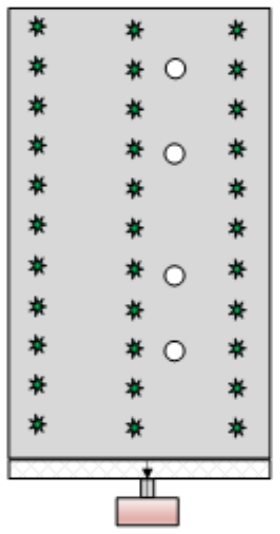

7YPM
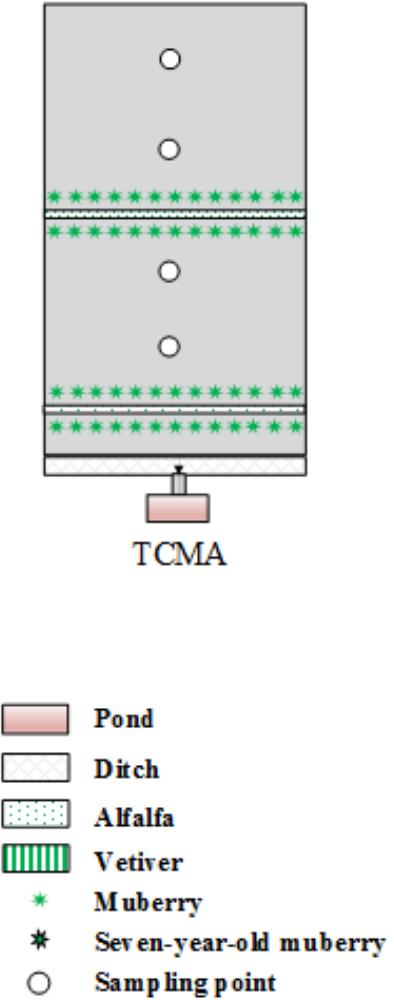

O Samp ling point

Figure 1. Arrangement of the experimental plots and sampling points.

\subsection{Sowing and Fertilizer Application}

During the experimental period, from 2017 to 2019, mustard plants were started in a nearby nursery in mid-September and transplanted into the experimental plots in midOctober of each year. The row spacing and plant spacing for mustard were both $40 \mathrm{~cm}$, and the mustard (Brassica juncea var.tumidaTsen etLee) was planted $60 \mathrm{~cm}$ from the hedge. One-year-old mulberry seedlings were transplanted into the 7YTM, 7YBM, and 7YPM plots in December 2010 and into the TM, TCMV, and TCMA plots in March 2017. In this study, 
the area of land occupied by hedgerows in each plot was used to calculate the reduction in the yields of the plots (Appendix A, Table A1).

The inorganic fertilization and maize-mustard rotation schemes applied represent common practices in the region. At planting, inorganic fertilizers such as N, P, and K were applied according to the conventional application rates used by local farmers. Inorganic fertilizers were applied at $280.80 \mathrm{~kg} \mathrm{~N} \mathrm{hm}^{-2}, 140.40 \mathrm{~kg} \mathrm{P}_{2} \mathrm{O}_{5} \mathrm{hm}^{-2}$, and $163.80 \mathrm{~kg} \mathrm{~K}_{2} \mathrm{O}$ $\mathrm{hm}^{-2}$ in each mustard season and $171.69 \mathrm{~kg} \mathrm{~N} \mathrm{hm}^{-2}, 140.47 \mathrm{~kg} \mathrm{P}_{2} \mathrm{O}_{5} \mathrm{hm}^{-2}$, and $78.04 \mathrm{~kg}$ $\mathrm{K}_{2} \mathrm{O} \mathrm{hm}^{-2}$ in each maize season. Just before applying fertilizers, soil bulk density (BD), soil mechanical composition, total nitrogen (STN), soil acid-hydrolyzable nitrogen (AHN), and soil organic carbon (SOC) were determined to ascertain the physical and chemical properties (Appendix A, Table A2).

This study investigated the spatial variation in soil physicochemical properties caused by soil erosion. To eliminate the influence of soil movement caused by tillage equipment on the redistribution of soil along the slope, we performed minimal tillage (plowing at $15 \mathrm{~cm}$ ) on all plots only at the beginning of the experiment in early March 2017 and did not till the soils in the following two years. According to local farmers, pruning mulberry trees every year in December is a common practice. Generally, the farmers prune the mulberry trees to approximately $40 \mathrm{~cm}$ from ground level and remove the pruned materials from the plot. They also typically leave mustard residues in the field after harvest because the roots and leaves can function as green manure for the next crop after fermentation and decay. Moreover, to avoid the adverse effects of herbicide and pesticide use on the soil environment and soil characteristics, manual weeding and pest control measures were carried out in the plots.

\subsection{Crop Sample Harvesting and Soil Sample Analyses}

At crop maturity (in February 2019), the fresh mustard yield was determined by harvesting and weighing all the mustard tubers in each plot. Before harvesting, three representative mustard samples were randomly collected near each sampling point, as shown in Figure 1. Here, "representative mustard samples" refers to mustard of moderate size that does not grow in border areas, and all mustard yields in subsequent chapters refer to fresh mustard tubers.

After the mustard harvest, soil samples ( 1000 g) were collected at the sampling points using a screw auger. We restricted our sampling depth to the top $0-20 \mathrm{~cm}$ of soil because this depth has the highest soil nutrient and SOC concentrations and responds strongly to land use practices [33]. To minimize land gradient effects, three undisturbed soil cores were collected near each sampling point using a 7.6-cm-internal-diameter auger and were uniformly mixed into one composite sample. Visible roots and stones were removed from the samples, and the fresh soil samples were passed through a $2 \mathrm{~mm}$ sieve. A subsample of each soil sample was air-dried, ground, sieved, and stored in a sealed bag for physical and chemical analysis. The rest of each sample was stored in a refrigerator at $4{ }^{\circ} \mathrm{C}$ and processed shortly after sampling.

The soil particle size distribution was determined with the laser diffraction method using a laser particle analyzer (Mastersizer 2000, Malvern, UK). The soil texture was classified according to the international particle size classification. The soil BD was determined from undisturbed soil samples using intact cores ( $0.15 \mathrm{~m}$ deep, $0.05 \mathrm{~m}$ diameter).

The soil total nitrogen (STN) was measured by the micro-Kjeldahl method. SOC was determined by the modified Walkley-Black wet oxidation procedure. The soil $\mathrm{pH}$ was determined with a 1:2.5 (soil-water) ratio using an electrode-equipped $\mathrm{pH}$ meter. The soil organic $\mathrm{N}$ fractions were analyzed in acid hydrolysate and prepared by heating the soil samples with $6 \mathrm{~mol} \mathrm{~L}^{-1} \mathrm{HCl}$ in a $120^{\circ} \mathrm{C}$ autoclave for $12 \mathrm{~h}$ [34].

\subsection{Data Analysis and Statistics}

To identify the effects of different crop-hedgerow intercropping systems and topography on the soil properties, statistical analyses were conducted using SPSS 24.0. One-way 
analysis of variance (ANOVA) was performed to evaluate the variances in crop yield and soil physicochemical properties under the different slope positions at the 0.05 significance level by Fisher's least significant difference (LSD) test. Moreover, Pearson correlation coefficient analysis was applied to analyze the relationships between the soil variables, crop-hedgerow intercropping types, and slope positions, and a significance test was conducted at a $95 \%$ confidence level. The correlations were considered to be statistically significant at $p<0.05$.

\section{Results}

\subsection{Mustard Yield as Influenced by Slope Position}

Mustard yield varied significantly $(p<0.05)$ between the crop-hedgerow intercropping treatments, and the treatments in order from highest to lowest yield were: TCMA $\left(60.75 \mathrm{Mg} \mathrm{ha}^{-1}\right)>\operatorname{TCMV}\left(59.88 \mathrm{Mg} \mathrm{ha}^{-1}\right)>\mathrm{TM}\left(55.32 \mathrm{Mg} \mathrm{ha}^{-1}\right)>\mathrm{CT}\left(55.30 \mathrm{Mg} \mathrm{ha}^{-1}\right)>$ 7YTM (51.05 Mg ha ${ }^{-1}$ ) > 7YBM (45.52 $\mathrm{Mg} \mathrm{ha}^{-1}$ ) > 7YPM (38.86 Mg ha ${ }^{-1}$ ) (Figure 2). There was no significant difference in mustard yield between the TCMA and TCMV treatments $(p>0.05)$, but both of them had significantly higher mustard yields than the other treatments. Compared with that of CT, the mustard yields of the TCMV and TCMA treatments were $8.28 \%$ and $9.86 \%$ higher, respectively, while those of the 7YTM, 7YBM, and 7YPM treatments were $7.69 \%, 17.69 \%$, and $29.73 \%$ lower, respectively. Interestingly, although the TM and 7YTM treatments were both two-belt mulberry hedgerow systems, the mustard yield of the former was $0.04 \%$ higher than that in CT, while that of the latter was $7.69 \%$ lower than that in CT. Of these two treatments, the former was a newly planted mulberry hedgerow, and the latter was a mulberry hedgerow that had been growing for 7 years; their crop yields were significantly different $(p<0.05)$ (Figure 2).

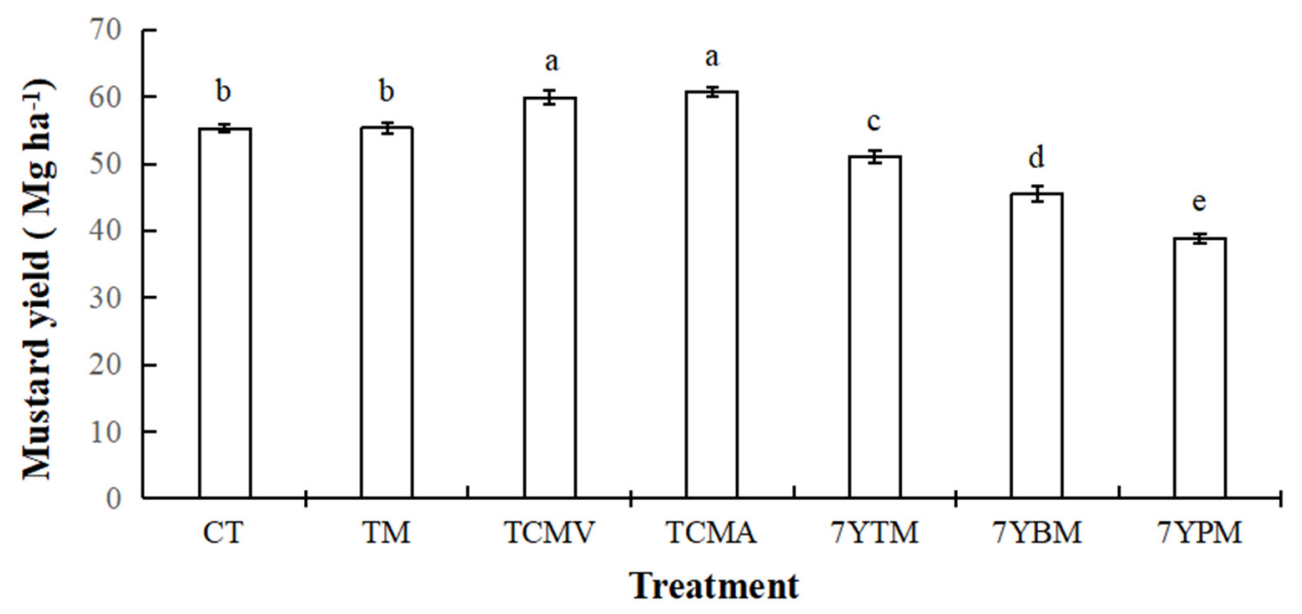

Figure 2. Impacts of crop-hedgerow intercropping systems on mustard yield. Values are means \pm standard deviations. Different lowercase letters above each bar indicate significant differences at $p<0.05$.

The average weight of individual fresh mustard tuber samples (WMS) was significantly higher in the lower slope position than in the upper slope position in all treatments except 7YPM (Figure 3). The WMS increased significantly from the upper position to the lower position in CT, TM, and 7YBM. In TCMV, TCMA, and 7YTM, there were no significant differences in mustard yield between the upper-middle and lower-middle slope positions. Among the different treatments, there were significant differences in WMS at the same slope position. In the upper slope position, the WMS of 7YPM was significantly higher than those of the other treatments, while in the upper-middle, lower-middle, and lower slope positions, the WMSs of TCMV and TCMA were significantly higher than those of the other treatments. 


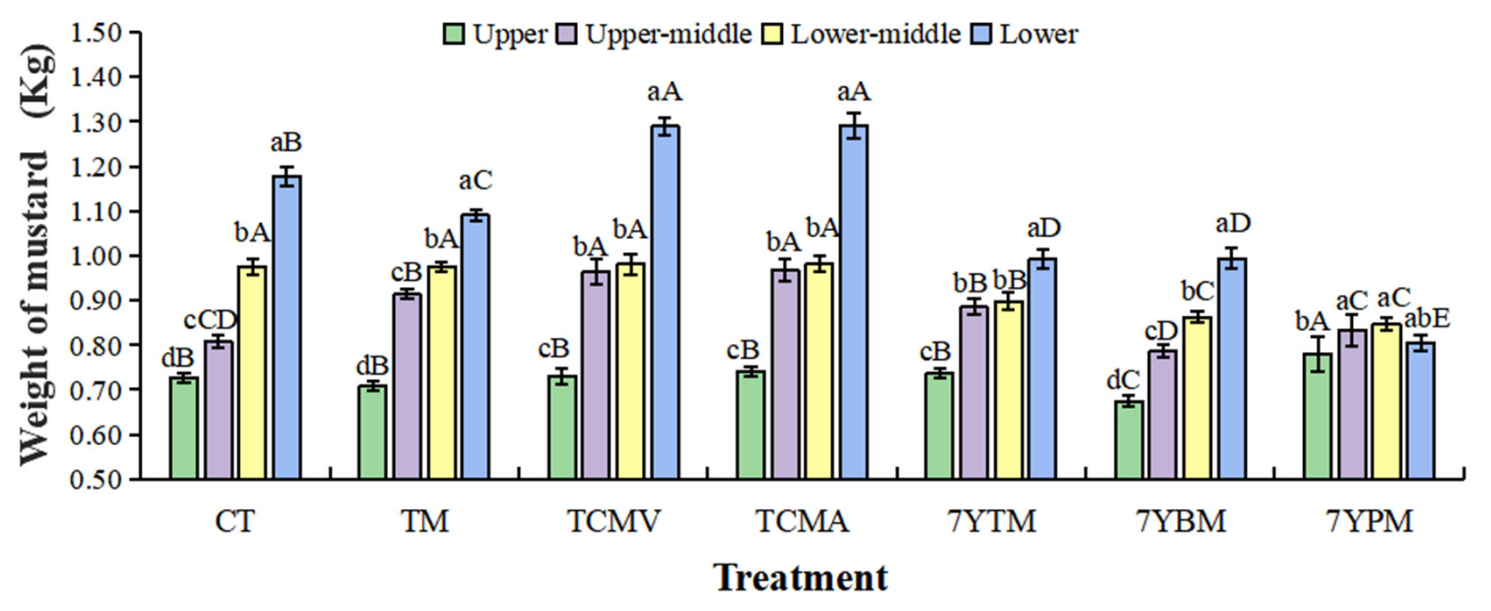

Figure 3. Effects of slope position on the average weight of mustard samples (WMS) under different crop-hedgerow intercropping treatments at the same slope position. Different lowercase letters above the bars indicate means that are significantly different among different slope positions within the same treatment at $p<0.05$. Different uppercase letters above the bars indicate means that are significantly different among the different treatments at the same slope position at $p<0.05$.

\subsection{Soil Physical Properties as Influenced by Slope Position}

The different crop-hedgerow intercropping systems significantly influenced $(p<0.05)$ soil physical properties, such as the soil particle composition (clay, sand, and silt) and soil $\mathrm{BD}$, and their values varied with slope position.

The clay content increased significantly with decreasing slope position in all treatments (Figure 4a). The average clay contents of TM, TCMV, TCMA, 7YTM, 7YBM, and 7YPM were $19.07 \%, 27.30 \%, 22.67 \%, 19.49 \%, 23.48 \%$, and $20.28 \%$ higher than those of CT, respectively. Compared with that at the upper slope position, the clay contents at the upper-middle, lower-middle, and lower slope positions were $5.51 \%, 10.13 \%$, and $12.22 \%$ higher, respectively. A sequential downslope increase in clay content was observed in $\mathrm{CT}$ and TM, but different trends were observed in other treatments. For example, there was no significant difference in clay content between the upper-middle position and the lower-middle position in the TCMV and TCMA treatments, and no significant difference between the lower-middle position and the lower position in the 7YTM, 7YBM, and 7YPM treatments. In the 7YPM treatment, there was no significant difference between the upper position and the upper-middle position or between the lower-middle position and the lower position.

Silt tended to accumulate at the lower slope position in TM (Figure $4 \mathrm{~b}$ ), but no clear trends were observed in the other treatments. Averaged across the intercropping systems, the silt contents were $5.51 \%, 10.13 \%$, and $12.22 \%$ higher at the upper-middle, lower-middle, and lower slope positions, respectively, than at the upper slope position.

In contrast, the sand content decreased significantly down the slope in CT, TM, TCMV, TCMA, and 7YTM, whereas in 7YBM and 7YPM, this hardly changed among the four slope positions (Figure 4c). Regardless of the intercropping system, the sand content at the upper-middle, lower-middle, and lower slope positions was $9.13 \%, 13.88 \%$, and $19.45 \%$ lower, respectively, than that at the upper slope position.

A significant decrease in $\mathrm{BD}$ was observed with decreasing slope position. The soil $\mathrm{BD}$ ranged from 1.28 to $1.30 \mathrm{~g} \mathrm{~cm}^{-3}$, and the differences between different treatments were not significant $(p>0.05)$ (Figure 5). Of the treatments, 7YPM and 7YBM had lower soil BD, while $\mathrm{CT}$ and TM had higher soil BD. The soil $\mathrm{BD}$ at the end of the two years in 2019 under 7YPM, 7YBM, 7YTM, TCMV, TCMA, and TM was $1.7 \%, 1.19 \%, 0.96 \%, 0.94 \%, 0.92 \%$, and $0.55 \%$ lower, respectively, than that under CT. 

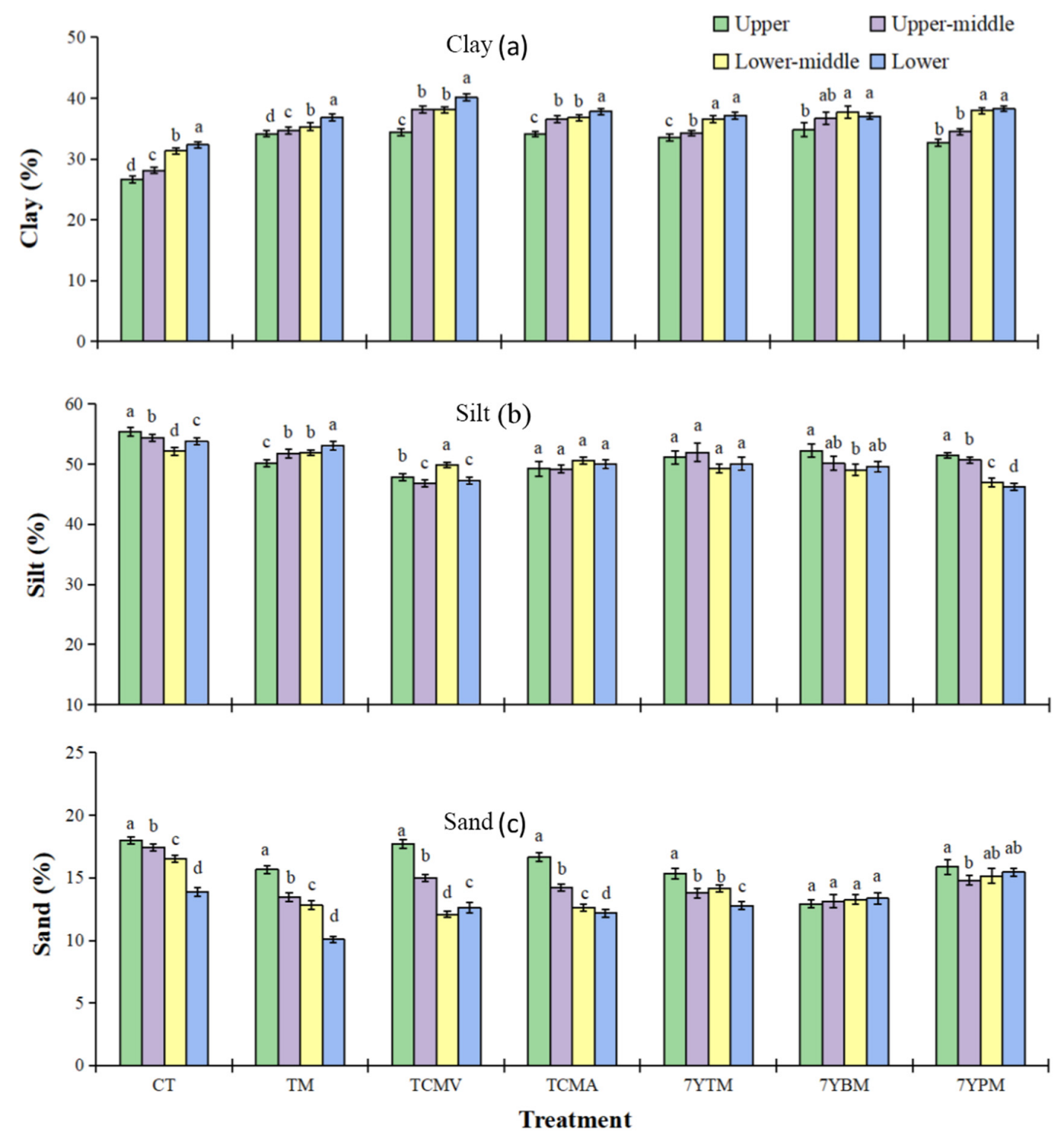

Figure 4. Clay, Silt, and Sand as influenced by slope under different crop-hedgerow intercropping systems. Different letters above the bars indicate means that are significantly different between different slope positions within the same treatment at $p<0.05$.

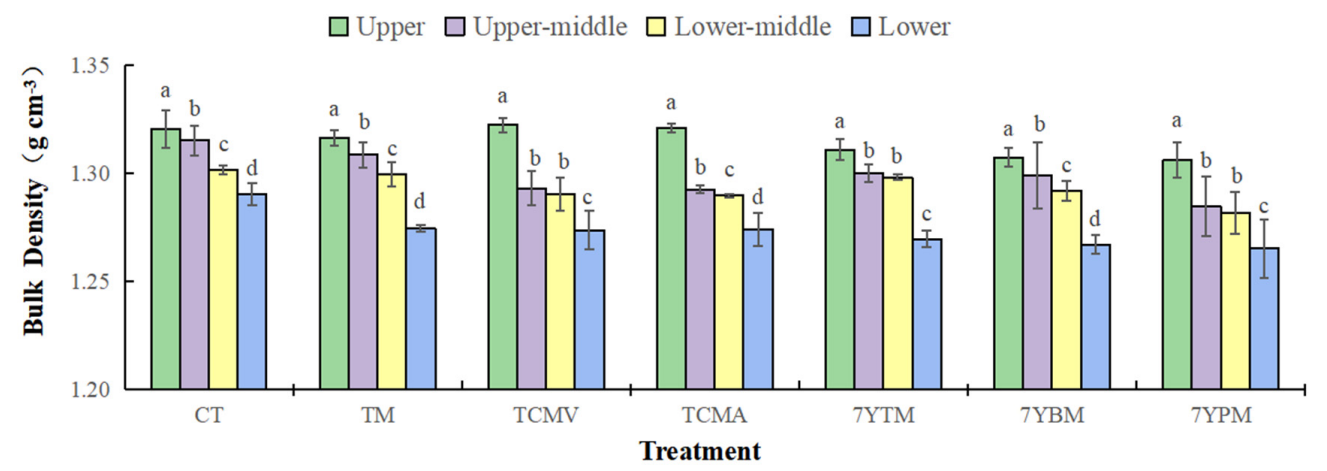

Figure 5. Soil bulk density as influenced by slope position under different crop-hedgerow intercropping systems. Different letters above the bars indicate means that are significantly different between slope positions within the same crop-hedgerow intercropping system at $p<0.05$. Error bars signify the standard errors of the means. 
Different trends in the distributions of soil BD were observed among the different slope positions. Generally, as the slope position decreased, the soil BD also decreased significantly $(p<0.05)$. However, there were some subtle differences between the various slope positions. There was almost no difference in $\mathrm{BD}$ between the upper-middle position and the lower-middle position in TCMV, 7YTM, and 7YPM.

\subsection{Soil Chemical Properties as Influenced by Slope Position}

Slope position had a significant $(p \leq 0.05)$ influence on soil chemical properties under the different crop-hedgerow intercropping systems (Table 1).

Table 1. Characteristics of the distributions of soil properties at different slope positions.

\begin{tabular}{|c|c|c|c|c|c|c|}
\hline Treatment & Slope Position & STN $\left(\mathrm{g} \mathrm{kg}^{-1}\right)$ & AHN (g kg $\left.{ }^{-1}\right)$ & SOC $\left(\mathrm{g} \mathrm{kg}^{-1}\right)$ & $\mathbf{C} / \mathbf{N}$ & $\mathrm{pH}$ \\
\hline \multirow{5}{*}{$\mathrm{CT}$} & Upper & $0.92 \pm 0.00^{\mathrm{d}}$ & $0.67 \pm 0.01^{d}$ & $7.28 \pm 0.07^{\mathrm{d}}$ & $7.90 \pm 0.10^{b}$ & $7.32 \pm 0.07^{\mathrm{a}}$ \\
\hline & Upper-middle & $0.96 \pm 0.00^{c}$ & $0.72 \pm 0.01^{c}$ & $7.52 \pm 0.08^{c}$ & $7.82 \pm 0.10^{b}$ & $5.51 \pm 0.05^{b}$ \\
\hline & Lower-middle & $1.00 \pm 0.01^{b}$ & $0.75 \pm 0.01^{b}$ & $7.81 \pm 0.08^{b}$ & $7.82 \pm 0.12^{b}$ & $5.12 \pm 0.05^{c}$ \\
\hline & Lower & $1.05 \pm 0.01^{\mathrm{a}}$ & $0.79 \pm 0.01^{\mathrm{a}}$ & $8.88 \pm 0.15^{\mathrm{a}}$ & $8.45 \pm 0.22^{\mathrm{a}}$ & $5.01 \pm 0.05^{\mathrm{d}}$ \\
\hline & Mean & $0.98 \pm 0.05^{\mathrm{B}}$ & $0.73 \pm 0.04^{\mathrm{B}}$ & $7.87 \pm 0.64^{\mathrm{B}}$ & $8.00 \pm 0.30 \mathrm{AB}$ & $5.01 \pm 0.05^{\mathrm{d}}$ \\
\hline \multirow{4}{*}{$\mathrm{TM}$} & Upper & $0.94 \pm 0.01^{\mathrm{c}}$ & $0.70 \pm 0.01^{\mathrm{c}}$ & $7.48 \pm 0.06^{c}$ & $7.97 \pm 0.14^{b}$ & $5.74 \pm 0.97^{\mathrm{C}}$ \\
\hline & Upper-middle & $1.01 \pm 0.02^{\mathrm{b}}$ & $0.77 \pm 0.02^{b}$ & $7.94 \pm 0.07^{\mathrm{b}}$ & $7.87 \pm 0.21^{b}$ & $7.68 \pm 0.08^{b}$ \\
\hline & Lower-middle & $1.01 \pm 0.02^{b}$ & $0.77 \pm 0.01^{b}$ & $7.93 \pm 0.07^{b}$ & $7.82 \pm 0.18^{b}$ & $7.47 \pm 0.08^{c}$ \\
\hline & Lower & $1.12 \pm 0.02^{\mathrm{a}}$ & $0.85 \pm 0.02^{\mathrm{a}}$ & $9.49 \pm 0.08^{a}$ & $8.60 \pm 0.16^{a}$ & $6.90 \pm 0.07^{\mathrm{d}}$ \\
\hline \multirow{6}{*}{ TCMV } & Mean & $1.02 \pm 0.07^{\mathrm{B}}$ & $0.77 \pm 0.06^{\mathrm{B}}$ & $8.21 \pm 0.80^{\mathrm{B}}$ & $8.04 \pm 0.32^{\mathrm{A}}$ & $7.48 \pm 0.38^{\mathrm{A}}$ \\
\hline & Upper & $0.99 \pm 0.01^{c}$ & $0.74 \pm 0.02^{\mathrm{c}}$ & $7.66 \pm 0.05^{c}$ & $7.76 \pm 0.02^{\mathrm{a}}$ & $7.59 \pm 0.08^{a}$ \\
\hline & Upper-middle & $1.13 \pm 0.01^{\mathrm{b}}$ & $0.86 \pm 0.02^{b}$ & $8.63 \pm 0.06^{b}$ & $7.61 \pm 0.03^{b}$ & $7.20 \pm 0.07^{b}$ \\
\hline & Lower-middle & $1.15 \pm 0.01^{\mathrm{b}}$ & $0.87 \pm 0.02^{b}$ & $8.70 \pm 0.06^{b}$ & $7.58 \pm 0.10^{b}$ & $6.82 \pm 0.07^{c}$ \\
\hline & Lower & $1.20 \pm 0.00^{\mathrm{a}}$ & $0.94 \pm 0.02^{\mathrm{a}}$ & $9.73 \pm 0.07^{\mathrm{a}}$ & $7.84 \pm 0.05^{\mathrm{a}}$ & $5.84 \pm 0.07^{\mathrm{d}}$ \\
\hline & Mean & $1.13 \pm 0.10^{\mathrm{A}}$ & $0.85 \pm 0.08^{\mathrm{A}}$ & $8.68 \pm 0.76^{\mathrm{A}}$ & $7.70 \pm 0.12^{C}$ & $6.86 \pm 0.68^{\mathrm{AB}}$ \\
\hline \multirow{4}{*}{ TCMA } & Upper & $0.98 \pm 0.02^{c}$ & $0.74 \pm 0.01^{\mathrm{c}}$ & $7.61 \pm 0.07^{c}$ & $7.74 \pm 0.15^{\mathrm{a}}$ & $7.76 \pm 0.18^{a}$ \\
\hline & Upper-middle & $1.19 \pm 0.01^{b}$ & $0.90 \pm 0.02^{b}$ & $8.66 \pm 0.08^{b}$ & $7.28 \pm 0.16^{b}$ & $7.33 \pm 0.10^{b}$ \\
\hline & Lower-middle & $1.20 \pm 0.01^{b}$ & $0.90 \pm 0.02^{b}$ & $8.81 \pm 0.08^{b}$ & $7.30 \pm 0.12^{b}$ & $6.43 \pm 0.08^{c}$ \\
\hline & Lower & $1.25 \pm 0.01^{\mathrm{a}}$ & $0.95 \pm 0.02^{a}$ & $9.90 \pm 0.10^{\mathrm{a}}$ & $7.93 \pm 0.08^{a}$ & $6.04 \pm 0.01^{\mathrm{d}}$ \\
\hline \multirow{6}{*}{ 7YTM } & Mean & $1.16 \pm 0.1^{\mathrm{A}}$ & $0.88 \pm 0.09^{\mathrm{A}}$ & $8.75 \pm 0.86^{\mathrm{A}}$ & $7.56 \pm 0.31^{C}$ & $6.83 \pm 0.77^{\mathrm{B}}$ \\
\hline & Upper & $0.98 \pm 0.02^{c}$ & $0.74 \pm 0.02^{c}$ & $7.68 \pm 0.06^{c}$ & $7.81 \pm 0.11^{a b}$ & $7.90 \pm 0.08^{a}$ \\
\hline & Upper-middle & $1.12 \pm 0.00^{\mathrm{b}}$ & $0.85 \pm 0.01^{b}$ & $8.46 \pm 0.07^{b}$ & $7.58 \pm 0.06^{c}$ & $7.60 \pm 0.08^{b}$ \\
\hline & Lower-middle & $1.11 \pm 0.01^{\mathrm{b}}$ & $0.85 \pm 0.02^{b}$ & $8.54 \pm 0.07^{\mathrm{b}}$ & $7.73 \pm 0.07^{b c}$ & $7.03 \pm 0.08^{c}$ \\
\hline & Lower & $1.20 \pm 0.01^{\mathrm{a}}$ & $0.93 \pm 0.01^{\mathrm{a}}$ & $9.60 \pm 0.08^{a}$ & $7.95 \pm 0.10^{\mathrm{a}}$ & $6.38 \pm 0.07^{\mathrm{d}}$ \\
\hline & Mean & $1.10 \pm 0.08^{\mathrm{A}}$ & $0.84 \pm 0.07^{\mathrm{A}}$ & $8.56 \pm 0.70^{\mathrm{A}}$ & $7.77 \pm 0.16^{\mathrm{BC}}$ & $7.23 \pm 0.61 \mathrm{AB}$ \\
\hline \multirow{4}{*}{ 7YPM } & Upper & $1.14 \pm 0.02^{c}$ & $0.88 \pm 0.02^{b c}$ & $8.04 \pm 0.06^{c}$ & $7.05 \pm 0.10^{c}$ & $6.94 \pm 0.10^{\mathrm{a}}$ \\
\hline & Upper-middle & $1.24 \pm 0.02^{\mathrm{a}}$ & $0.96 \pm 0.04^{\mathrm{a}}$ & $9.81 \pm 0.07^{\mathrm{a}}$ & $7.89 \pm 0.09^{b}$ & $6.62 \pm 0.10^{b}$ \\
\hline & Lower-middle & $1.09 \pm 0.03^{\mathrm{d}}$ & $0.84 \pm 0.02^{c}$ & $7.94 \pm 0.06^{c}$ & $7.25 \pm 0.18^{c}$ & $5.70 \pm 0.08^{c}$ \\
\hline & Lower & $1.18 \pm 0.01^{\mathrm{b}}$ & $0.90 \pm 0.02^{b}$ & $9.61 \pm 0.07^{b}$ & $8.15 \pm 0.10^{a}$ & $5.02 \pm 0.07^{\mathrm{d}}$ \\
\hline \multirow{6}{*}{ 7YBM } & Mean & $1.16 \pm 0.06^{\mathrm{A}}$ & $0.90 \pm 0.05^{\mathrm{A}}$ & $8.85 \pm 0.90^{\mathrm{A}}$ & $7.59 \pm 0.48^{C}$ & $7.20 \pm 0.61 \mathrm{AB}$ \\
\hline & Upper & $1.06 \pm 0.04^{\mathrm{d}}$ & $0.80 \pm 0.03^{c}$ & $7.62 \pm 0.04^{\mathrm{d}}$ & $7.22 \pm 0.23^{b}$ & $7.86 \pm 0.12^{\mathrm{a}}$ \\
\hline & Upper-middle & $1.13 \pm 0.03^{c}$ & $0.86 \pm 0.02^{b}$ & $8.74 \pm 0.04^{c}$ & $7.74 \pm 0.22^{\mathrm{a}}$ & $7.56 \pm 0.12^{b}$ \\
\hline & Lower-middle & $1.18 \pm 0.01^{\mathrm{b}}$ & $0.90 \pm 0.20^{b}$ & $8.72 \pm 0.04^{b}$ & $7.39 \pm 0.09^{b}$ & $7.00 \pm 0.11^{\mathrm{c}}$ \\
\hline & Lower & $1.25 \pm 0.01^{\mathrm{a}}$ & $0.96 \pm 0.02^{\mathrm{a}}$ & $9.76 \pm 0.07^{\mathrm{a}}$ & $7.84 \pm 0.09^{a}$ & $6.35 \pm 0.10^{d}$ \\
\hline & Mean & $1.15 \pm 0.08^{\mathrm{A}}$ & $0.88 \pm 0.06^{\mathrm{A}}$ & $8.71 \pm 0.79 \mathrm{~A}$ & $7.55 \pm 0.30^{C}$ & $6.08 \pm 0.80^{C}$ \\
\hline
\end{tabular}

Values are means \pm standard deviations. Different uppercase and lowercase letters in the same column indicate significant differences in soil chemical properties between different slope positions at $p<0.05$.

STN increased significantly with decreasing slope position in all treatments except 7YPM. STN differed significantly between the different crop-hedgerow intercropping systems and decreased in the order 7YPM $\left(1.16 \mathrm{~g} \mathrm{~kg}^{-1}\right)>$ TCMA $\left(1.16 \mathrm{~g} \mathrm{~kg}^{-1}\right)>7$ YBM $\left(1.15 \mathrm{~g} \mathrm{~kg}^{-1}\right)>\operatorname{TCMV}\left(1.13 \mathrm{~g} \mathrm{~kg}^{-1}\right)>7 \mathrm{YTM}\left(1.10 \mathrm{~g} \mathrm{~kg}^{-1}\right)>\mathrm{TM}\left(1.02 \mathrm{~g} \mathrm{~kg}^{-1}\right)$; these values were $18.42 \%, 17.71 \%, 17.20 \%, 14.64 \%, 12.11 \%$, and $3.73 \%$ higher, respectively, than that under CT. The STN contents of TM and CT were significantly lower than those of the other 
treatments $(p<0.05)$. The new and old two-belt mulberry hedgerow systems (TM, TCMV, TCMA and 7YTM) showed no significant $(p>0.05)$ difference in STN content between the upper-middle position and the lower-middle position $(p>0.05)$, but the STN contents of these two slope positions were significantly different from those of the upper slope position and the lower slope position.

The AHN content accounted for approximately $70-80 \%$ of the STN. Among the different crop-hedgerow intercropping systems, the distribution of AHN exhibited a very similar trend to that of STN. The AHN content was the lowest in $\mathrm{CT}$, which had no hedgerows, and was $5.48 \%, 16.44 \%, 20.55 \%, 15.07 \%, 20.55 \%$, and $23.29 \%$ lower than that in TM, TCMV, TCMA, 7YTM, 7YBM, and 7YPM, respectively. In all the intercropping systems except the TM treatment, the AHN content was significantly different from that in CT $(p<0.05)$.

The SOC content varied with slope position under the different crop-hedgerow intercropping systems (Table 1). Similar to the STN and AHN contents, in all treatments except 7YPM, the SOC content in the lower slope position was the highest and was significantly different from those in the other slope positions. Compared with $\mathrm{CT}$, the other treatments showed significantly higher SOC content in the topsoil, with the highest values in the 7YPM treatment. The different crop-hedgerow systems had no significant effect on SOC accumulation $(p>0.05)$ (Table 1$)$.

The ANOVA results indicated no significant difference $(p>0.05)$ in the $\mathrm{C} / \mathrm{N}$ ratio among the different slope positions (Table 1). The soil $\mathrm{C} / \mathrm{N}$ ratio ranged from 6.14 to 8.13 (Table 1), and the coefficient of variation was $19.7 \%$. The variation in the $\mathrm{C} / \mathrm{N}$ ratio between different treatments was low, indicating that the $\mathrm{C} / \mathrm{N}$ ratio was relatively stable in crop-hedgerow intercropping systems.

The $\mathrm{pH}$ decreased significantly $(p<0.05)$ with decreasing slope position in all treatments. The $\mathrm{pH}$ value ranged from 5.02 to 7.90 (Table 1), with an average value of 6.78, and the mean soil $\mathrm{pH}$ at the upper slope position $(7.53 \pm 0.41)$ was significantly $(p<0.05)$ higher than that at the lower slope position $(5.71 \pm 0.73)$. The variation in the soil $\mathrm{pH}$ was the largest in the CT treatment, where the $\mathrm{pH}$ ranged from 7.32 at the upper slope position to 5.01 at the lower slope position.

\subsection{Correlation between Yield and Soil Parameters}

The Pearson's correlation coefficient matrix is shown in Table 2. The correlations between WMS and soil parameters and among soil parameters were calculated.

Table 2. Pearson correlations between the assessed variables: position; WMS; BD; silt, sand, and clay contents; STN, AHN, $\mathrm{SOC}, \mathrm{C} / \mathrm{N}$, and $\mathrm{pH}$.

\begin{tabular}{|c|c|c|c|c|c|c|c|c|c|c|}
\hline & Position & WMS & BD & Silt & Sand & Clay & STN & AHN & SOC & $\mathrm{C} / \mathrm{N}$ \\
\hline WMS & $0.735^{* *}$ & - & - & - & - & - & - & - & - & - \\
\hline $\mathrm{BD}$ & $-0.866^{* *}$ & $-0.541^{* *}$ & - & - & - & - & - & - & - & - \\
\hline Silt & $-0.183^{\mathrm{ns}}$ & $-0.027^{\mathrm{ns}}$ & $0.367^{* *}$ & - & - & - & - & - & - & - \\
\hline Sand & $-0.598^{* *}$ & $-0.597 * *$ & $0.623 * *$ & $0.031^{\mathrm{ns}}$ & - & - & - & - & - & - \\
\hline Clay & $0.509 * *$ & $0.412 * *$ & $-0.664^{* *}$ & $-0.739 * *$ & $-0.658^{* *}$ & - & - & - & - & - \\
\hline STN & $0.601 * *$ & $0.445^{* *}$ & $-0.823^{* *}$ & $-0.436^{* *}$ & $-0.582^{* *}$ & $0.706^{* *}$ & - & - & - & - \\
\hline $\mathrm{AHN}$ & $0.590 * *$ & $0.421^{* *}$ & $-0.816^{* *}$ & $-0.440^{* *}$ & $-0.596^{* *}$ & $0.715^{* *}$ & $0.971^{* *}$ & - & - & - \\
\hline $\mathrm{SOC}$ & $0.769 * *$ & $0.581 * *$ & $-0.898^{* *}$ & $-0.324 * *$ & $-0.619 * *$ & $0.627 * *$ & $0.882 * *$ & 0.872 ** & - & - \\
\hline $\mathrm{C} / \mathrm{N}$ & $0.399 * *$ & $0.329 * *$ & $-0.212^{\mathrm{ns}}$ & $0.214^{\mathrm{ns}}$ & $-0.125^{\mathrm{ns}}$ & $-0.118^{\mathrm{ns}}$ & $-0.173^{\mathrm{ns}}$ & $-0.137^{\mathrm{ns}}$ & 0.310 ** & - \\
\hline $\mathrm{pH}$ & $-0.698^{* *}$ & $-0.537^{* *}$ & $0.492 * *$ & $-0.056^{\mathrm{ns}}$ & $0.204^{\mathrm{ns}}$ & $-0.073^{\mathrm{ns}}$ & $-0.324^{* *}$ & $-0.307^{* *}$ & $-0.428^{* *}$ & -0.247 * \\
\hline
\end{tabular}

Pearson coefficient correlation analysis showed that the WMS had a significant negative correlation with $\mathrm{BD}$, sand content, and $\mathrm{pH}(\mathrm{r}=-0.541, p<0.01 ; \mathrm{r}=-0.597, p<0.01$; $\mathrm{r}=-0.537, p<0.01$, respectively) and a significant positive correlation with clay content, STN, AHN, SOC, and C $/ \mathrm{N}(\mathrm{r}=0.412, p<0.01 ; \mathrm{r}=0.445, p<0.01 ; \mathrm{r}=0.421, p<0.01 ; \mathrm{r}=0.581$, $p<0.01 ; \mathrm{r}=0.329, p<0.01$, respectively). This indicated that a change in WMS was associated with changes in slope position, STN, AHN, SOC, C/N, pH, and clay and sand 
contents. The slope position was positively correlated $(r=0.399-0.769)$ with WMS, clay content, STN, AHN, SOC, and C/N and negatively correlated ( $\mathrm{r}=0.598-0.866)$ with BD, sand content, and $\mathrm{pH}$. The $\mathrm{pH}$ was negatively correlated with slope position, WMS, STN, AHN, and SOC. A higher STN was associated with higher clay content, SOC, and AHN.

BD was inversely correlated with clay content, STN, AHN, and SOC ( $\mathrm{r}=-0.664$, $p<0.01 ; \mathrm{r}=-0.823, p<0.01 ; \mathrm{r}=-0.816, p<0.01 ; \mathrm{r}=-0.898, p<0.01$, respectively) (Table 2) but had a direct correlation with sand content. This indicated that a change in BD was associated with changes in soil organic matter and clay and sand contents.

The silt content had a significant correlation with $\mathrm{BD}(\mathrm{r}=0.367, p<0.05)$ and a significant negative correlation $(\mathrm{r}=0.664-0.898 ; P<0.05)$ with soil chemical properties, namely, STN, AHN, and SOC (Table 2). The sand content had a significant negative correlation $(\mathrm{r}=0.582-0.619 ; p<0.05)$ with soil chemical properties, namely, STN, AHN, and SOC. The clay content had significant positive correlation with STN, AHN, and SOC $(\mathrm{r}=0.706, p<0.01 ; \mathrm{r}=0.715, p<0.01 ; \mathrm{r}=0.627, p<0.01$, respectively).

In addition, STN was very positively correlated with AHN and SOC ( $\mathrm{r}=0.971$, $p<0.01 ; \mathrm{r}=0.882, p<0.01)$ but negatively correlated with $\mathrm{pH}(\mathrm{r}=-0.324, p<0.01)$; soil AHN was significantly (r2 $=0.872 ; p<0.01)$ positively correlated with SOC.

\section{Discussion}

\subsection{Effects of Different Hedgerow Intercropping Systems on Mustard Yield and Soil} Physicochemical Properties

Among all the crop-hedgerow intercropping systems assessed in this study, the TCMV and TCMA systems produced the highest crop yields (Figure 2). This could be ascribed to the positive complementary impacts of the compound contour hedgerows (a mulberry hedgerow and a grass filter belt) on soil physicochemical properties. Under the local conventional fertilization rates, TCMV and TCMA could have favorable effects on soil physicochemical properties, such as reducing the soil BD (Figure 5), improving the soil pH, and maintaining soil nutrient concentrations (Table 1); in turn, these effects may have a positive effect on crop yield.

In general, the soil BD decreased in the order 7YPM $>$ 7YBM $>$ TCMA $>$ TCMV $>$ 7YTM $>$ TM $>$ CT. A lower BD is conducive to root penetration and plant growth and development and, thus, benefits crop yields $[26,35,36]$. Compared with that of TC, the BD values of TCMV and TCMA were lower (Figure 5); there are several possible reasons for this result. First, the canopy coverage of the TCMV and TCMA systems was higher than that of the TC treatment. This higher canopy coverage may have decreased splash erosion of the soil by raindrops, which may have resulted in less soil compaction. Liu et al. [37] suggested that canopies can effectively protect soil surfaces from raindrop impacts, thus inhibiting splash erosion. Through rainfall simulation experiments, Schmidt [38] found that the surface of the soil can be lowered due to raindrop impacts and that the soil particles detached by rainfall are transported by water into coarse soil pores, which decreases the total soil volume. Second, compared with CT and TM, TCMV and TCMA had higher yields of plant residues; these residues may have decomposed and created biopore channels, thus reducing soil compaction and the soil BD. Ketema, H. et al. [39] found that the soil $\mathrm{BD}$ under an agroforestry management model was lower than that under a conventional management model; they attributed this difference to the higher soil organic matter levels under the agroforestry management model, which improved the soil porosity, aggregate formation, and structure. This finding was further reinforced in this study by the significant inverse correlation observed between mustard yield and soil BD (Table 2). Oshunsanya et al. [26] attributed the increased crop yield to the decrease in BD, which may have reduced soil resistance to root penetration and increased root development.

The STN, AHN, OC, and $\mathrm{pH}$ in all of the tested crop-hedgerow intercropping systems were higher than those in CT (Table 1). This may be because crop-hedgerow intercropping systems can reduce soil nutrient loss through hedgerow interception (including intercepting rainfall to reduce runoff and filtering runoff to reduce sediment loss) [23]. In addition, the dead roots and leaves of hedgerow species remain in the soil, which is conducive 
to the accumulation of soil organic matter [40]. As an important element of soil fertility regulation, organic matter maintains and improves the productivity of sloped farmland. In this study, the higher soil nutrient content and higher OC content in the TCMV and TCMA systems than in the other systems (Table 1), and the significant correlation between yield and nutrients, both fully support this viewpoint (Table 2). However, although both TM and 7YTM were two-belt mulberry hedgerow treatments, 7YTM had a thicker root system, denser branches and leaves, and greater litter contributions to the soil than TM, which resulted in the accumulation of more organic matter and nutrients in the soil but lower crop yields. This result may have occurred because the strong hedgerow plants in the older crop-hedgerow intercropping system are more competitive for soil nutrients, water, and sunlight than the crops, so the resultant crop yields are inevitably reduced. However, as they are the main food source for silkworms, the economic value created by mulberry plants can completely offset the adverse effects of crop yield reduction. It should be noted that, although the soil BD was the lowest under the 7YBM and 7YPM treatments, the crop yields from these treatments were also the lowest among all the crophedgerow intercropping treatments. This discrepancy was due to the competition from the hedgerow plants for sunlight, water, and nutrients, which the local farmers found unacceptable. Table 1 shows that among the newly planted mulberry hedgerow systems, the STN, AHN, and SOC contents of the compound mulberry hedgerow systems (such as TCMV and TCMA) were significantly higher than those of TM. However, there was no significant difference in these soil properties between the newly planted compound mulberry hedgerow systems and the older mulberry hedgerow systems (such as 7YTM, 7YBM, and 7YPM). In summary, the TCMV and TCMA systems were the most beneficial for controlling soil erosion, retaining soil nutrients, and maintaining soil productivity.

\subsection{Slope Position Affects Mustard Yield and Soil Physicochemical Properties}

In this field experiment, the differential retention of nutrients in runoff and of eroded sediments by the different hedgerow systems resulted in spatial differences in crop yields and soil physicochemical properties. In terms of crop yield, the lower slope position produced significantly higher yields than the upper slope position (Figure 3), which is consistent with the research conclusions of Changere et al. [41]. In their study, the lower slope position produced the highest maize yield, and the average yield of the lower position was $36.9 \%$ and $56.8 \%$ higher than those of the upper and middle slope positions, respectively. Several subsequent studies further confirmed this trend [42-44]. These differences may be due to the selective migration of fine, nutrient-rich aggregates from the upper slope to the lower slope through soil erosion. Topography plays an important role in water distribution, nutrient levels, organic matter, soil texture, and other soil properties and, in turn, in plant growth and crop production; therefore, it affects crop yield and yield variability [42]. In this study, the differences in hedgerow planting patterns and planting time led to differences in the morphology and structure of the hedgerow belts; these differences, in turn, necessarily led to differences in the physical segmentation of the topography, which inevitably led to spatial variations in the soil physicochemical properties. Although TM, TCMV, and TCMA included two-belt contour hedgerows, the crop yield of TM significantly $(p<0.05)$ increased as the slope position decreased, while the differences in the crop yields of TCMV and TCMA between the upper and lower slopes were not significant $(p>0.05)$. This may be because the hierarchical structure of TCMV and TCMA was superior to that of a single hedgerow, which not only had the mulberry hedge layer with luxuriant branches and leaves on the upper layer, but also had the grass filter layer covering the ground. The dense branches and leaves of the upper layer of the mulberry hedgerows reduced splash erosion caused by raindrops; in addition, the grass filter provided high ground coverage, and its dense leaves controlled runoff erosion well. The combination of mulberry hedgerows and grass filters addressed the problems with single mulberry hedgerows. In a single mulberry hedgerow, the mulberry branches and leaves do not come into close contact with the ground, and there is a large gap between the 
branches and leaves and the ground. Therefore, single mulberry hedgerows cannot control surface runoff erosion well.

The highest sand content (Figure 4) and the lowest STN, AHN, and OC contents (Figure 3) in all treatments were recorded at the upper slope position. This trend may indicate that the soil at the upper slope position tended to erode during heavy rainfall events. Due to the absence of hedgerows to protect the soil surface at the upper slope position from raindrops, the rainfall detached the finer particles of the topsoil, and these particles were deposited at the lower slope position. This result is consistent with reported findings that clay is a finer, lighter material that is more susceptible to erosion than sand particles $[33,45,46]$. These results also agree with the results of Gitari et al. [12], who reported significantly greater deposition of clay particles at a lower slope position than at an upper slope position. Similarly, Dessalegn et al. [30] pointed out that the high clay content at the foot of slopes may be due to the removal of fine soil particles from steeper slopes and their deposition at lower slope positions. In this study, the contents of clay and organic matter in the upper position were low, while those in the lower position were high, and the BD values in the upper and lower positions were high and low, respectively; these results are consistent with the results of Miheretu et al. [33]. They also show that organic matter is essential for aggregating soil particles and reducing soil compaction, which promotes water penetration and protects the physical properties of the soil.

In this study, the significantly higher concentrations of TN, AHN, and SOC at the lower slope position suggest that soil nutrients were enriched at the lower slope position due to soil erosion (Table 1). Although the concentrations of STN, AHN, and SOC at the lower slope position were significantly higher than those at the other slope positions, there was almost no difference in these properties between the upper-middle and lower-middle slope positions in the TM, 7YTM, TCMA, and TCMV treatments (Table 1). These results indicate that contour hedgerows planted on a cross-slope can effectively change the flow direction and reduce the flow velocity of runoff, thus reducing the nutrient loss caused by soil erosion in the area covered by the hedgerow canopy. In addition, the litter in the hedgerow plots also increased the roughness of the surface soil, which further reduced the runoff velocity. These two factors may be responsible for the higher soil nutrient contents at the upper-middle and lower-middle slope positions. The vegetation coverage on sloping farmland affects runoff generation and soil loss. Vieira et al. [47] found that reductions in vegetation coverage make the soil more susceptible to raindrops, thereby promoting the separation of soil aggregates. Luo et al. [48] demonstrated that vegetation coverage on sloped farmland decreased the rill flow velocity and increased flow resistance. These factors explain why the soil erosion rate was greater in CT than in the crop-hedgerow intercropping systems.

\section{Conclusions}

Of all the treatments, the TCMV and TCMA systems had the highest crop yields and the greatest ability to reduce the spatial variability of the soil physicochemical properties. These results indicate that the ability of compound contour hedgerows (mulberry hedgerows and grass filters) to retain runoff, eroded sediments, and nutrients could be a major factor in maintaining the beneficial physicochemical properties of soil. The TCMV and TCMA systems effectively reduce the runoff velocity through the shrub layer and grass filter layer; increase the contact time between the surface soil and runoff, which increases the absorption of nutrients in runoff by the soil; retain eroded sediments in the system. At the local conventional fertilization rates, TCMV and TCMA could promote favorable soil physicochemical conditions, such as reduced soil $\mathrm{BD}$, improved soil $\mathrm{pH}$, and increased soil nutrient levels. These conditions may have a positive effect on crop yield. The results of this study can be explained in three ways. First, compared to the other treatments, TCMV and TCMA had more branches and leaves, which reduced the effects of splash erosion from raindrops on the topsoil, thus reducing soil compaction and decreasing erosion and sediment losses. Second, the hedgerow litter increased soil roughness and soil 
erosion resistance. Third, the return of the hedgerow litter to the soil was conducive to increasing the amount of soil organic matter. The compound contour hedgerows in this study improved soil properties and thus increased crop yields. Furthermore, the physical interception of runoff by hedgerows can allow nutrients to be retained in the upper-middle and lower-middle slope positions, which makes the soil physicochemical properties more consistent among the different slope positions. It is important to improve soil fertility and reduce the variations in soil physicochemical properties caused by soil erosion by adopting contoured, compound, hedgerow-intercropping systems and adjusting the amount of fertilizer applied at each slope position. These approaches should be further investigated in future studies. This study may have implications for farming practices in the sloping farmlands of the TGR region and could provide guidance regarding how to maintain soil quality as well as crop yields by implementing appropriate intercropping patterns and reasonable fertilization at each slope position.

Author Contributions: D.X., J.N. and P.L. conceptualized the research and performed the validation; methodology, C.N., J.N. and D.X. administered the project, developed the methodology, curated the data, conducted the formal analysis, P.L., C.N. and S.W. reviewed and edited the manuscript. D.X., F.C., S.W. and P.L. acquired funding. All the authors contributed to drafting the manuscript. All authors have read and agreed to the published version of the manuscript.

Funding: This work was supported by the National Nature Science Foundation of China (41807071 and 41671291), the Fundamental Research Funds for the Central Universities (swu19038), and the Sichuan Provincial Department of Education Foundation of China (18ZA0268).

Institutional Review Board Statement: This study did not involve humans or animals.

Informed Consent Statement: This study did not report any data.

Conflicts of Interest: None of the authors has competing/conflicting interests in relation to the issues discussed in this manuscript.

\section{Appendix A}

Table A1. Fresh mustard yield and Converted yield.

\begin{tabular}{cccc}
\hline Treatment & $\left.\begin{array}{c}\text { Harvesting Fresh Mustard } \\
\text { Yield (Mg ha }\end{array}{ }^{-\mathbf{1}}\right)$ & $\begin{array}{c}\text { Planting Density } \\
\text { (Plants ha }^{-\mathbf{1})}\end{array}$ & Converted Yield (Mg ha $^{-\mathbf{1})}$ \\
\hline CT & $55.30 \pm 0.22^{\mathrm{a}}$ & 60,000 & $55.30 \pm 0.22^{\mathrm{b}}$ \\
TM & $37.62 \pm 0.41^{\mathrm{c}}$ & 40,800 & $55.32 \pm 0.60^{\mathrm{b}}$ \\
TCMV & $40.72 \pm 0.74^{\mathrm{b}}$ & 40,800 & $59.88 \pm 1.10^{\mathrm{a}}$ \\
TCMA & $41.31 \pm 0.12^{\mathrm{b}}$ & 40,800 & $60.75 \pm 0.17^{\mathrm{a}}$ \\
7YTM & $34.72 \pm 0.26^{\mathrm{d}}$ & 40,800 & $51.05 \pm 0.39^{\mathrm{c}}$ \\
7YPM & $24.48 \pm 0.36^{\mathrm{f}}$ & 30,000 & $38.86 \pm 0.57^{\mathrm{e}}$ \\
7YBM & $29.13 \pm 0.73^{\mathrm{e}}$ & 35,200 & $45.52 \pm 1.14^{\mathrm{d}}$ \\
\hline
\end{tabular}

The data in the table are the mean value \pm SD. Different lower case letters at the same column indicate a significant difference at the $5 \%$ level.

Table A2. Initial soil physical and chemical properties of the study site.

\begin{tabular}{cccc}
\hline Soil Parameters & & \\
\hline Bulk density & $1.34 \mathrm{~g} \mathrm{~cm}^{-3}$ & STN & $0.94\left(\mathrm{~g} \mathrm{~kg}^{-1}\right)$ \\
Clay (\%) & 26.62 & AHN & $0.72\left(\mathrm{~g} \mathrm{~kg}^{-1}\right)$ \\
Silt (\%) & 55.38 & SOC & $6.38\left(\mathrm{~g} \mathrm{~kg}^{-1}\right)$ \\
Sand (\%) & 18.00 & $\mathrm{pH}$ & 6.25 \\
\hline
\end{tabular}




\section{References}

1. Liu, H.; Yao, L.; Lin, C.; Wang, X.; Wang, H.; Xu, W. 18-year grass hedge effect on soil water loss and soil productivity on sloping cropland. Soil Tillage Res. 2018, 177, 12-18. [CrossRef]

2. Rodrigo Comino, J.; Iserloh, T.; Lassu, T.; Cerda, A.; Keestra, S.D.; Prosdocimi, M.; Brings, C.; Marzen, M.; Ramos, M.C.; Senciales, J.M.; et al. Quantitative comparison of initial soil erosion processes and runoff generation in Spanish and German vineyards. Sci. Total Environ. 2016, 565, 1165-1174. [CrossRef]

3. Smetanová, A.; Follain, S.; David, M.; Ciampalini, R.; Raclot, D.; Crabit, A.; Le Bissonnais, Y. Landscaping compromises for land degradation neutrality: The case of soil erosion in a Mediterranean agricultural landscape. J. Environ. Manag. 2019, 235, $282-292$. [CrossRef]

4. Duan, J.; Liu, Y.; Yang, J.; Tang, C.; Shi, Z. Role of groundcover management in controlling soil erosion under extreme rainfall in citrus orchards of southern China. J. Hydrol. 2020, 582, 124290. [CrossRef]

5. Qadir, M.; Quillérou, E.; Nangia, V.; Murtaza, G.; Singh, M.; Thomas, R.J.; Drechsel, P.; Noble, A.D. Economics of salt-induced land degradation and restoration. Nat. Resour. Forum. 2014, 38, 282-295. [CrossRef]

6. Wessels, K.J.; Prince, S.D.; Malherbe, J.; Small, J.; Frost, P.E.; VanZyl, D. Can human-induced land degradation be distinguished from the effects of rainfall variability? A case study in South Africa. J. Arid. Environ. 2007, 68, 271-297. [CrossRef]

7. Lenka, N.K.; Dass, A.; Sudhishri, S.; Patnaik, U.S. Soil carbon sequestration and erosion control potential of hedgerows and grass filter strips in sloping agricultural lands of eastern India. Agric. Ecosyst. Environ. 2012, 158, 31-40. [CrossRef]

8. Cerdan, O.; Govers, G.; Le Bissonnais, Y.; Van Oost, K.; Poesen, J.; Saby, N.; Gobin, A.; Vacca, A.; Quinton, J.; Auerswald, K.; et al. Rates and spatial variations of soil erosion in Europe: A study based on erosion plot data. Geomorphology 2010, 122, 167-177. [CrossRef]

9. Lin, C.; Tu, S.; Huang, J.; Chen, Y. The effect of plant hedgerows on the spatial distribution of soil erosion and soil fertility on sloping farmland in the purple-soil area of China. Soil Tillage Res. 2009, 105, 307-312. [CrossRef]

10. Shi, Z.; Chen, L.; Cai, C.; Li, Z.; Liu, G. Effects of long-term fertilization and mulch on soil fertility in contour hedgerow systems: A case study on steeplands from the Three Gorges Area, China. Nutr. Cycl. Agroecosys 2009, 84, 39-48. [CrossRef]

11. Zhong, S.; Han, Z.; Li, J.; Xie, D.; Yang, Q.; Ni, J. Mechanized and Optimized Configuration Pattern of Crop-Mulberry Systems for Controlling Agricultural Non-Point Source Pollution on Sloping Farmland in the Three Gorges Reservoir Area, China. Int. J. Environ. Res. Public Health 2020, 17, 3599. [CrossRef]

12. Gitari, H.I.; Gachene, C.K.K.; Karanja, N.N.; Kamau, S.; Nyawade, S.; Schulte-Geldermann, E. Potato-legume intercropping on a sloping terrain and its effects on soil physico-chemical properties. Plant Soil 2019, 438, 447-460. [CrossRef]

13. Asadi, H.; Raeisvandi, A.; Rabiei, B.; Ghadiri, H. Effect of land use and topography on soil properties and agronomic productivity on calcareous soils of a semiarid region, Iran. Land Degrad. Dev. 2012, 23, 496-504. [CrossRef]

14. Kouselou, M.; Hashemi, S.; Eskandari, I.; McKenzie, B.M.; Karimi, E.; Rezaei, A.; Rahmati, M. Quantifying soil displacement and tillage erosion rate by different tillage systems in dryland northwestern Iran. Soil Use Manag. 2018, 34, 48-59. [CrossRef]

15. Fan, F.; Xie, D.; Wei, C.; Ni, J.; Yang, J.; Tang, Z.; Zhou, C. Reducing soil erosion and nutrient loss on sloping land under crop-mulberry management system. Environ. Sci. Pollut. Res. 2015, 22, 14067-14077. [CrossRef]

16. Zhang, Q.; Chen, S.; Dong, Y.; Liu, D.; Yang, X.; Yang, Z. Controllability of Phosphorus Losses in Surface Runoff from Sloping Farmland Treated by Agricultural Practices. Land Degrad. Dev. 2017, 28, 1704-1716. [CrossRef]

17. Liu, Y.; Yang, J.; Hu, J.; Tang, C.; Zheng, H. Characteristics of the surface-subsurface flow generation and sediment yield to the rainfall regime and land-cover by long-term in-situ observation in the red soil region, Southern China. J. Hydrol. 2016, 539, 457-467. [CrossRef]

18. $\mathrm{Wu}, \mathrm{L} . ;$ Long, T.; Li, C. The simulation research of dissolved nitrogen and phosphorus non-point source pollution in Xiao-Jiang watershed of Three Gorges Reservoir area. Water Sci. Technol. 2010, 61, 1601-1616. [CrossRef]

19. Joslin, A.H.; Vasconcelos, S.S.; de Assis Oliviera, F.; Kato, O.R.; Morris, L.; Markewitz, D. A Slash-and-Mulch Improved-Fallow Agroforestry System: Growth and Nutrient Budgets over Two Rotations. Forests 2019, 10, 1125. [CrossRef]

20. Angima, S.D.; Stott, D.E.; O’Neill, M.K.; Ong, C.K.; Weesies, G.A. Use of calliandra-Napier grass contour hedges to control erosion in central Kenya. Agric. Ecosyst. Environ. 2002, 91, 15-23. [CrossRef]

21. Xia, L.; Hoermann, G.; Ma, L.; Yang, L. Reducing nitrogen and phosphorus losses from arable slope land with contour hedgerows and perennial alfalfa mulching in Three Gorges Area, China. Catena 2013, 110, 86-94. [CrossRef]

22. Wang, L.; Tang, L.; Wang, X.; Chen, F. Effects of alley crop planting on soil and nutrient losses in the citrus orchards of the Three Gorges Region. Soil Tillage Res. 2010, 110, 243-250. [CrossRef]

23. Wang, T.; Zhu, B.; Xia, L. Effects of Contour Hedgerow Intercropping on Nutrient Losses from the Sloping Farmland in the Three Gorges Area, China. J. Mt. Sci. Engl. 2012, 9, 105-114. [CrossRef]

24. Fan, J.; Yan, L.; Zhang, P.; Zhang, G. Effects of grass contour hedgerow systems on controlling soil erosion in red soil hilly areas, Southeast China. Int. J. Sediment Res. 2015, 30, 107-116. [CrossRef]

25. Adhikary, P.P.; Hombegowda, H.C.; Barman, D.; Jakhar, P.; Madhu, M. Soil erosion control and carbon sequestration in shifting cultivated degraded highlands of eastern India: Performance of two contour hedgerow systems. Agrofor. Syst. 2017, 91, 757-771. [CrossRef]

26. Oshunsanya, S.O.; Li, Y.; Yu, H. Vetiver grass hedgerows significantly reduce nitrogen and phosphorus losses from fertilized sloping lands. Sci. Total Environ. 2019, 661, 86-94. [CrossRef] [PubMed] 
27. Chen, F.; Wang, X.; Li, X.; Wang, J.; Xie, D.; Ni, J.; Liu, Y. Using the sediment fingerprinting method to identify the sediment sources in small catchments with similar geological conditions. Agr. Ecosyst. Environ. 2019, 286, 106655. [CrossRef]

28. Zhu, H.; Zhang, L.M. Field investigation of erosion resistance of common grass species for soil bioengineering in Hong Kong. Acta Geotech. 2016, 11, 1047-1059. [CrossRef]

29. Hao, Y.; Lal, R.; Owens, L.B.; Izaurralde, R.C.; Post, W.M.; Hothem, D.L. Effect of cropland management and slope position on soil organic carbon pool at the North Appalachian Experimental Watersheds. Soil Tillage Res. 2002, 68, 133-142. [CrossRef]

30. Dessalegn, D.; Beyene, S.; Ram, N.; Walley, F.; Gala, T.S. Effects of topography and land use on soil characteristics along the toposequence of Ele watershed in southern Ethiopia. Catena 2014, 115, 47-54. [CrossRef]

31. Hosseini Bai, S.; Blumfield, T.J.; Reverchon, F. The impact of mulch type on soil organic carbon and nitrogen pools in a sloping site. Biol. Fert. Soils 2014, 50, 37-44. [CrossRef]

32. Sánchez, I.A.; Lassaletta, L.; McCollin, D.; Bunce, R.G.H. The effect of hedgerow loss on microclimate in the Mediterranean region: An investigation in Central Spain. Agroforest. Syst. 2010, 78, 13-25. [CrossRef]

33. Miheretu, B.A.; Yimer, A.A. Spatial variability of selected soil properties in relation to land use and slope position in Gelana sub-watershed, Northern highlands of Ethiopia. Phys. Geogr. 2018, 39, 230-245. [CrossRef]

34. Stevenson, F.J. Nitrogen-Organic Forms; Bigham, J.M., Ed.; SSSA; ASA: Madison, WI, USA, 1996; pp. 1185-1200.

35. Whalley, W.R.; Watts, C.W.; Gregory, A.S.; Mooney, S.J.; Clark, L.J.; Whitmore, A.P. The effect of soil strength on the yield of wheat. Plant Soil 2008, 306, 237-247. [CrossRef]

36. Twum, E.K.A.; Nii-Annang, S. Impact of Soil Compaction on Bulk Density and Root Biomass of Quercus petraea L. at Reclaimed Post-Lignite Mining Site in Lusatia, Germany. Appl. Environ. Soil Sci. 2015, 2015, 504603. [CrossRef]

37. Liu, T.; Luo, J.; Zheng, Z.; Li, T.; He, S. Effects of rainfall intensity on splash erosion and its spatial distribution under maize canopy. Nat. Hazards. 2016, 84, 233-247. [CrossRef]

38. Schmidt, J. Wasserhaushalt und Feststofftransport an Geneigten, Landwirtschaftlich Bearbeiteten Nutzflächen. Ph.D. Thesis, Freie Universität, Berlin, Germany, 1988.

39. Ketema, H.; Yimer, F. Soil property variation under agroforestry based conservation tillage and maize based conventional tillage in Southern Ethiopia. Soil Tillage Res. 2014, 141, 25-31. [CrossRef]

40. Dilla, A.M.; Smethurst, P.J.; Huth, N.I.; Barry, K.M. Plot-Scale Agroforestry Modeling Explores Tree Pruning and Fertilizer Interactions for Maize Production in a Faidherbia Parkland. Forests 2020, 11, 1175. [CrossRef]

41. Changere, A.; Lal, R. Slope Position and Erosional Effects on Soil Properties and Corn Production on a Miamian Soil in Central Ohio. J. Sustain. Agric. 1997, 11, 5-21. [CrossRef]

42. Ajami, M.; Heidari, A.; Khormali, F.; Zeraatpisheh, M.; Gorji, M.; Ayoubi, S. Spatial Variability of Rainfed Wheat Production Under the Infuence of Topography and Soil Properties in Loess-Derived Soils, Northern Iran. Int. J. Plant Prod. 2020, 14, 597-608. [CrossRef]

43. Walley, F.; Pennock, D.; Solohub, M.; Hnatowich, G. Spring wheat (Triticum aestivum) yield and grain protein responses to N fertilizer in topographically defined landscape positions. Can. J. Soil Sci. 2001, 81, 505-514. [CrossRef]

44. Grant, C.A.; Moulin, A.P.; Tremblay, N. Nitrogen Management Effects on Spring Wheat Yield and Protein Concentration Vary with Seeding Date and Slope Position. Agron. J. 2016, 108, 1246-1256. [CrossRef]

45. Tellen, V.A.; Yerima, B.P.K. Effects of land use change on soil physicochemical properties in selected areas in the North West region of Cameroon. Environ. Syst. Res. 2018, 7, 3. [CrossRef]

46. Gyssels, G.; Poesen, J.; Bochet, E.; Li, Y. Impact of plant roots on the resistance of soils to erosion by water. Prog. Phys. Geog. 2005, 2, 189-217. [CrossRef]

47. Vieira, D.C.S.; Serpa, D.; Nunes, J.P.C.; Prats, S.A.; Neves, R.; Keizer, J.J. Predicting the effectiveness of different mulching techniques in reducing post-fire runoff and erosion at plot scale with the RUSLE, MMF and PESERA models. Environ. Res. 2018, 165, 365-378. [CrossRef] [PubMed]

48. Luo, J.; Zheng, Z.; Li, T.; He, S. The changing dynamics of rill erosion on sloping farmland during the different growth stages of a maize crop. Hydrol. Process. 2019, 33, 76-85. [CrossRef] 